\title{
VERTEBRATE MICROREMAINS FROM THE PRAGIAN, EMSIAN AND EIFELIAN OF THE PRAGUE BASIN (CZECH REPUBLIC)
}

\author{
Michal Mergl${ }^{1}$, Valéria Vaškaninová ${ }^{2}$, Živilè Žigaite் ${ }^{2}$
}

${ }^{1}$ Centre of Biology, Geosciences and Environmental Sciences, Faculty of Education, University of West Bohemia in Plzeň, Klatovská 51, Plzeň, 30619, Czech Republic; E-mail: Argyrotheca@seznam.cz

2 Subdepartment of Evolution and Development, Department of Organismal Biology, Uppsala University, Norbyvägen 18 A, 75236 Uppsala, Sweden; E-mail: va.vaska@gmail.com, zivile.zigaite@gmail.com

\begin{abstract}
The vertebrate faunas in limestone samples of the Early and Middle Devonian ages (Pragian, early Emsian, late Emsian, and latest Eifelian) which were collected from five localities in the Barrandian area, Bohemia, include scales, tesserae, bones, and teeth of acanthodians, placoderms, chondrichthyans, and sarcopterygians. Although the vertebrate remains are not abundant the assemblages are significant in being dominated by particular taxa. Apart from undetermined microremains the genera Cheiracanthoides, Laliacanthus, Nostolepis, and Tassiliodus were determined.
\end{abstract}

Key words: Vertebrate microremains, Acanthodii, Placodermi, Chondrichthyes, Sarcopterygii, Devonian, Kačák Event, Prague Basin, Gondwana, Czech Republic

\section{INTRODUCTION}

Devonian vertebrate remains are rare in the Prague Basin (Barrandian area, Czech Republic). Barrande (1872) was the first to describe several fish remains. He determined them as Asterolepis, Coccosteus, Ctenacanthus, and Gompholepis, all being represented by incomplete dermal plates or fin spines (Barrande, 1872; pl. 28-30). Cross-sections of fin spines and fine superficial structures of preserved dermal plates, scales, or fin spines were figured by Barrande 1872; pls 28, 30. His determinations were revised since (Eastman, 1897; Bayer, 1905) and later new vertebrate remains from the Barrandian area were described or reviewed (von Koenen, 1895; Růžička, 1929; Gross, 1950, 1958, 1959, 1973; Vaškaninová \& Kraft, 2014a, 2014b, 2016; Vaškaninová \& Ahlberg, 2017).

No record of vertebrate microremains from the Devonian of the Prague Basin was published except for the acetic acid isolated scales of Machaeracanthus bohemicus Barrande, 1872 from the Lochkov Formation of Kosoř described and illustrated by Gross (1973) and acanthodian scales by Märss (1997) and Burrow et al. (2010b). However, the presence of vertebrate microremains in the Prague Basin was noted in the Chýnice Limestone (Mergl \& Ferrová, 2009), Suchomasty Limestone
(Mergl \& Jiménez, 2015), and Acanthopyge Limestone (Hladil et al., 1992; Mergl 2008) but without any additional data. They were picked from residues as a by-product of phosphatic brachiopod and conodont sampling. Despite their rarity, the vertebrate microremains, mostly scales, dermal bones and fin spines constitute a few distinct assemblages, which are described here. This contribution is a preliminary report about vertebrate microremains in the Prague Basin, Czech Republic.

\section{METHODS AND MATERIAL}

All vertebrate microremains were hand-picked from residues of limestone dissolved in $10 \%$ aceticacid solution. The histology of scales was not studied due to the rarity of the specimens. The morphological terminology of scales is adopted from Burrow \& Murphy (2016). Material descriptions are arranged stratigraphicaly.

All figured vertebrate microremains (except of a few specimens destroyed during SEM investigation) are housed in the palaeontological collections of the Centre of Biology, Earth and Environmental Sciences at the Faculty of Education of the University of West Bohemia in Plzeň (PCZCU). 


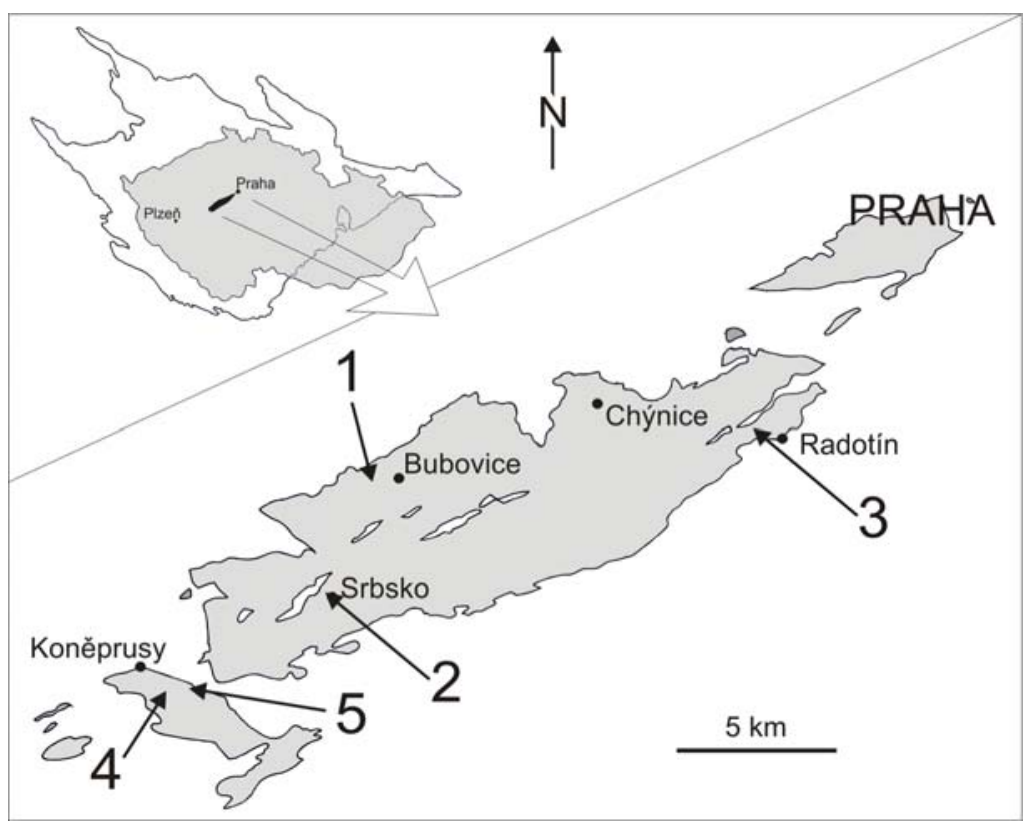

Figure 1. Outline of the Bohemian Massif, Czech Republic, and Devonian of the Barrandian area (top), and outcropping Devonian rocks of the Prague Basin (below), with marked localities which yielded vertebrate microremains: 1 - Sv. Jan, Solway's Quarries, 2 - Srbsko, 3 - Radotín, Hvižd'alka Quarry. 4 - Koněprusy, Na Voskopě (neptunic dykes), 5 - Konéprusy, Jirásek's Quarry.

\section{GEOLOGICAL SETTING OF SAMPLING LOCALITIES}

The stratigraphy of the Devonian of the Barrandian area is well known. Authors refer to the summary of Chlupáč (1998a), with additional data about special sections and localities commented by Hladil et al. (1992), Budil (1995), Chlupáč (1996, 1998b), Ferrová et al. (2012), and Vodrážková et al. (2013). A short review of four stratigraphic horizons and localities with vertebrate microremains is presented (Fig. 1).

\section{$1^{\text {ST }}$ HORIZON: PRAGIAN, PRAHA FORMATION, DVORCE-PROKOP LIMESTONE}

Vertebrate microremains are represented by chondrichthyan scales (Plate I, fig. 1-3) and an acanthodian tooth whorl (Plate I, fig. 4).

Locality: (1) Sv. Jan, Solway's Quarries, darkgrey limestone bed adjoining to the shale intercalation with Monograptus atopus Bouček, $M$. cf. yukonensis Jackson and M. aequabilis notoaequabilis Jaeger. Remains are associated with impoverished fauna (Chlupáč, 1998a) of acrotretid (Havlicekion, Opsiconidion), siphonotretid (Orbaspina) and discinoid brachiopods (Praeoehlertella) (Mergl, 2001), a chonetid Hemichonetes elegans Havlíček \& Racheboeuf, 1979, and small smooth-shelled rhynchonelliform brachiopods.

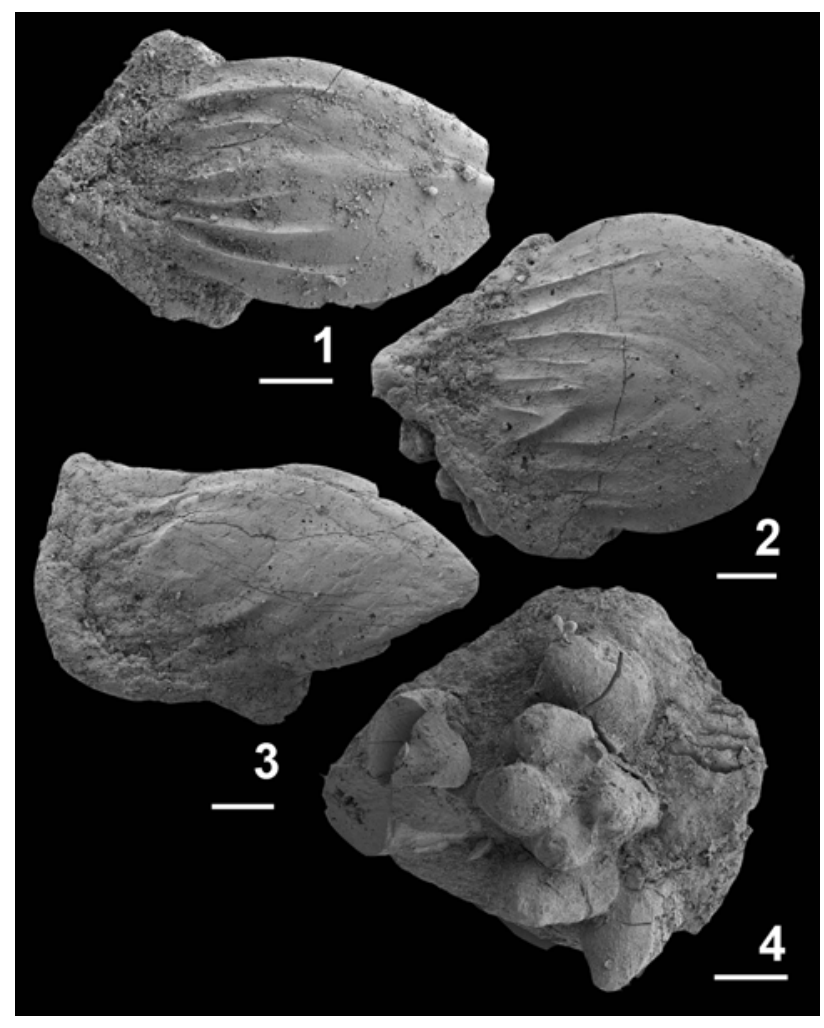

Plate I, 1-3 Chondrichthyes gen. et sp. indet., Pragian, Praha Formation, Dvorce-Prokop Limestone, locality Sv. Jan, Solway's Quarries; Scale bars $100 \mu \mathrm{m} ; 1$ - scale in crown view, PCZCU 2101; 2 - scale in crown view, PCZCU 2102; 3 - scale in crown view, PCZCU 2103; 4 - Acanthodii gen. et sp. indet., Pragian, Praha Formation, Dvorce-Prokop Limestone, locality Sv. Jan, Solway's Quarries; Scale bar $100 \mu \mathrm{m}$; tooth whorl in top view, PCZCU 2104. 


\section{Michal Mergl, Valéria Vaškaninová, Živilè Žigaitè, Vertebrate microremains from the Pragian}

\section{Plate II}

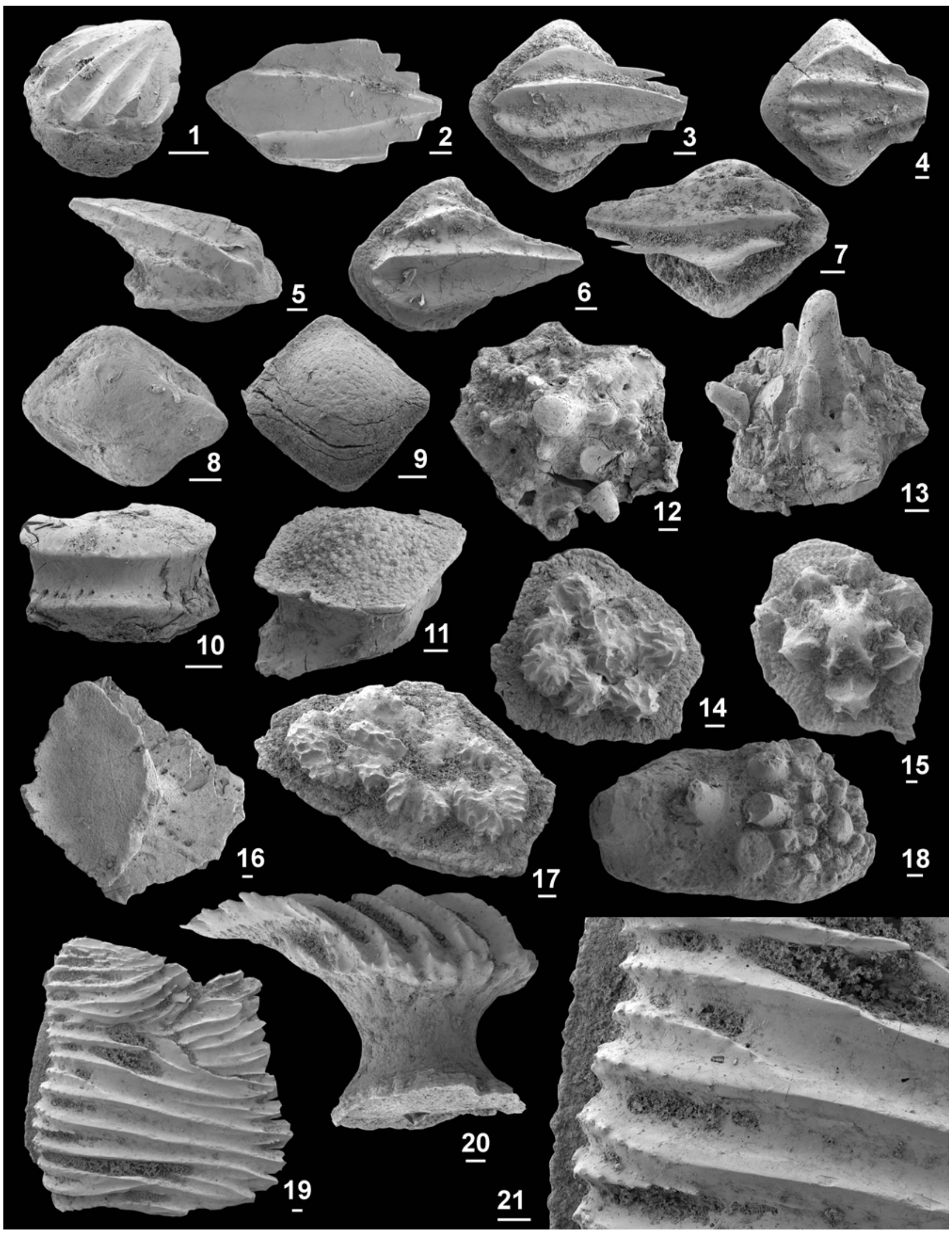


Plate II, 1 - Nostolepis sp., Eifelian/Givetian transition, Srbsko Formation, Kačák Member, "dark interval” above the Acanthopyge Limestone, Koněprusy, Jirásek?s Quarry locality; Scale bar $100 \mu \mathrm{m}$; scale in oblique view, destroyed.

2-7, 9, 11, 18 - Laliacanthus cf. singularis Karatajute-Talimaa, 1968, Lower Emsian, Zlíchov Formation, Chapel Coral Horizon; Radotín, Hvížd’alka Quarry locality; Scale bars $100 \mu \mathrm{m} ; 2$ - scale in crown view, PCZCU 2107; 3, 7 - scale in crown and latero-crown views, PCZCU 2109; 4 - scale in crown view, PCZCU 2108; 5, 6 - scale in oblique and crown views (destroyed); 9 - scale in base view, PCZCU 2105; 11 - scale in base-oblique view (destroyed); 18 - tooth whorl in top view, PCZCU 2010. 8 - Acanthodii gen. et sp. indet., Lower Emsian, Zlíchov Formation, Chapel Coral Horizon; Radotín, Hvížd’alka Quarry locality; Scale bar $100 \mu \mathrm{m}$; scale in crown view, PCZCU 2106.

10 - Cheiracanthoides sp., Eifelian/Givetian transition, Srbsko Formation, Kačák Member, “dark interval” above the Acanthopyge Limestone, Koněprusy, Jirásek's Quarry locality; Scale bar $100 \mu \mathrm{m}$; scale in anterior view, destroyed.

12, 13, 15 - Acanthothoraci gen. et sp. indet., Lower Emsian, Zlíchov Formation, Chapel Coral Horizon; Radotín, Hvížd’alka Quarry locality; Scale bars $100 \mu \mathrm{m} ; 12,13$ - tessera in crown and oblique view (destroyed); 15 - tessera, PCZCU 2111.

14, 17 - Chondrichthyes gen. et sp. indet., Lower Emsian, Zlíchov Formation, Chapel Coral Horizon; Radotín, Hvížd’alka Quarry locality; Scale bars $100 \mu \mathrm{m} ; 14$ - dermal plate in crown view (destroyed); 17 - dermal plate in crown view, PCZCU 2112. 16, 19-21 - Tassiliodus (?) sp., Lower Emsian, Zlíchov Formation, Chapel Coral Horizon; Radotín, Hvížd’alka Quarry locality; Scale bars $100 \mu \mathrm{m} ; 16$ - scale in base view, PCZCU 2113; 19, 21 - scale in crown view and detail of the crown ridges, PCZCU 2115; 20 - scale in side view, PCZCU 2114.

Class Acanthodii Owen, 1846

Acanthodii gen. et sp. indet.

Plate I, fig. 4

Description: The tooth whorl consists of 10 cusps in a chevron-like arrangement followed posteriorly by two cusps (Plate I, fig. 4). The base of the whorl is broadly rhomboidal.

Remarks: This type of whorl is common through the Lower Devonian, but cannot be assigned to any particular acanthodian.

Occurrence: Locality 1.

Class Chondrichthyes Huxley, 1880

Chondrichthyes gen. et sp. indet.

Plate I, figs 1-3

Description: The scales are $0.7-0.8 \mathrm{~mm}$ long, with square to rhomboidal flat base and elongate rhomboidal posteriorly displaced crown. The crown is low, extending behind the base by a flat rounded point. The margins of the crown are smooth. The surface of the crown bears up to eight low acute ridges with converging posterior ends. The ridges disappear at about midlenght of the crown. The posterior half of the crown is striated in the area paralleling the edges of the crown.

Remarks: The scales differ from other scales from the Prague Basin by weakly developed crown ridges and a low neck, and are similar to some chondrichthyan scales from the Middle Devonian of Australia (Pomeroy, 1994).

Occurrence: Locality 1.

\section{$2^{\text {ND }}$ HORIZON: LOWER EMSIAN, ZLÍCHOV FORMATION, CHAPEL CORAL HORIZON}

Vertebrate microremains are represented by acanthodian scales (Plate II, figs 2-9, 11) acanthodian tooth whorls (Plate II, fig. 18), acanthothoracid placoderm tesserae (Plate II, figs 12, 13, 15), and chondrichthyan scales (Plate II, figs 14, 16, 17, 19-21).

Localities: (2) Srbsko, natural outcrop of the Zlíchov Limestone in the slope above the road from Srbsko to Karlštejn, and (3) Radotín, Hvížd'alka Quarry, limestone boulders in the quarry scree. Vertebrate remains are associated with a very rich and taxonomically diverse fauna of corals, stromatoporoids, fenestrate bryozoans, rhynchonelliform brachiopods, trilobites, conulariids, rostroconchs, and other benthic fauna of reef origin (Havlíček, 1998) in both sampling sites. Beds rich in fossils represent recurrent accumulations of the biodetritic material in the talus of the early Emsian reef (Chlupáč, 1998a).

Class Acanthodii Owen, 1846

Family Climatiidae Berg, 1940

Genus Laliacanthus Karatajūtè-Talimaa, 1968

Laliacanthus cf. singularis Karatajūtè-Talimaa, 1968

Plate II, figs 2-7, 9, 11, 18

Description: The scales are up to $0.8 \mathrm{~mm}$ long, with highly convex subquadrate base. Moderately elevated strongly rhombic crown is ornamented 
with four ridges, in some scales with additional two short ridges near the anterior edge of the crown. The surface between the ridges is gently sulcate. The posterior part of the crown is sharply pointed. The posterolateral edges of the crown extend into small sharply pointed flat spines.

Remarks: The specimens are referred to Laliacanthus singularis Karatajütè-Talimaa, 1968 due to the elongate crown and spiny posterior crown. However, our scales are more elongate and spines at the posterior crown are shorter.

The scales are also similar to the scales of Nostolepis costata (Goujet, 1976). This species in known from the upper Lochkovian to the lower Pragian of Spain (Wang, 1993) as well as Saudi Arabia (Burrow et al., 2006) and Nevada (Burrow \& Murphy, 2016). A discussion about similarly shaped scales from other areas has been given by Burrow \& Murphy (2016). They indicate that N. costata is a widespread species along the Gondwanan shore of the Rheic and Palaeotethys oceans, but also illustrate intricate taxonomy of similarly shaped scales. All scales from the Zlíchov Formation differ from the specimens figured by Burrow \& Murphy (2016) by the spiny posterolateral edges but despite this difference and different age, the new formal name is not introduced. The Bohemian scales are rather similar to scales from the Jawf Formation of Saudi Arabia (Burrow et al., 2006), especially by the uneven posterolateral edges of the crown, which resemble the spiny edges of the Bohemian scales.

A single tooth whorl (Plate II, fig. 18) that could be referred to an acanthodian bears a cluster of cusps of uneven size on elongate base. Three large cusps form a row followed by similarly sized isolate cusps.

Occurrence: Localities 2 and 3.

Acanthodii gen. et sp. indet.

Plate II, fig. 8

Remarks: There is another scale difficult to determine due to extensive abrasion of the crown. Although it differs from the associated Laliacanthus cf. singularis Karatajūte-Talimaa, 1968 by the crown being smaller than the base, it might originate from the anterior parts of the body, the rostral or cephalic squamation.

Occurrence: Locality 3.

Class Placodermi M'Coy, 1848

Order Acanthothoraci Stensiö, 1944
Acanthothoraci gen. et sp. indet.

Plate II, figs 12, 13, 15

Description: The tesserae (Plate II, figs 12, 13) are circular and bear a highly conical central cusp at the centre of plate. The central cusp is surrounded by six radiating ridges, which bear three to four smaller nodes. The third tessera (Plate II, fig. 15) is subcircular and has a central larger tubercle surrounded by six smaller tubercles. The flat margin of the tessera is covered by small nodes.

Remarks: The tesserae can be tentatively referred to acanthothoracids. Similarly shaped tesserae were described from the Emsian of North Queensland, Australia by Pomeroy (1996; fig. 6J).

Class Chondrichthyes Huxley, 1880

Order incertae sedis

Genus Tassiliodus Derycke et Goujet, 2011

Tassiliodus (?) sp.

Plate II, figs 16, 19-21

Description: The scales are up to $2 \mathrm{~mm}$ long, variable in outline, with highly elevated crown on a rather thin neck (Plate II, fig. 20). The base is gently displaced anteriorly, generally rhombic but varying in outline, with acute margins and gently concave finely pitted surface. The crown is flat, much larger than the base, subquadrate to irregularly rhombic with the posterior corner extending far behind the base. The posterior and lateral edges of the crown are spinose. The surface of the crown bears 15 to 20 ridges in a streamlined arrangement, separated by weakly sulcate furrows. Some ridges may divide or fuse, or a new short ridge originates at the bottom of the furrow, but the majority of ridges originate at the anterior edge of the crown and extend into a short spine at the posterior edge. The crest of each ridge bears a single row of short spines in regular spacing, but the spines are present only in the anterior part of the crown. The neck of the crown bears some nick pores of variable size and arrangement (Plate II, fig. 16).

Remarks: The scales are rather similar to the scales of Tassiliodus lessardi Derycke \& Goujet (2011; fig. 6 D) from the Emsian of Algeria, but surely belong to different species. The spinose crests of the ridges, a flat to weakly concave base, thin neck, and variation in the outline of scales 
resemble scales of putative chondrichthyan Polymerolepis whitei Karatajute-Talimaa, 1968 (Hanke et al., 2013).

The scales are also similar to the acanthodian Milesacanthus, but our T. sp. differs by a flat to gently concave base, spiny crest of the crown ridge and by several pores at the crown neck. Milesacanthus antarctica Young \& Burrow, 2004 from the Aztec Siltstone of Antarctica shows a different arrangement of crown ridges, which are smooth (Young \& Burrow, 2004).

Occurrence: Localities 2 and 3.

Chondrichthyes gen. et sp. indet.

Plate II, figs 14, 17

Description: Three tesserae have a gently convex base and no discrete neck. The ornament consists of a central area of low closely packed serrated tubercles tapering to a rounded point. The tubercles have up to twelve radiating ridges lacking nodes. The larger tesserae have a more elongate outline and bear tubercles of uniform size, which are surrounded by a finely nodose depressed margin.
Remarks: Similar scales referred to chondrichthyes were described by Otto (1999; fig. 2, A1, A2) from the Middle Devonian of the Rheinisches Schiefergebirge, Germany.

Occurrence: Locality 3.

\section{$3^{R D}$ HORIZON: UPPER EMSIAN, DALEJE-TŘEBOTOV FORMATION, SUCHOMASTY LIMESTONE}

The vertebrate microremains of the Suchomasty Limestone are dominated by fragmental dermal bones of placoderms (Plate III, figs 1-7), accompanied by fewer tooth-like microremains with high apical cusp surrounded by six radiating ridges (Plate III, figs 8-10) that may belong to a chondrichthyan. No acanthodiid scales were detected. All remains come from the infillings of neptunian dykes penetrating the reef forming the Koněprusy Limestone of Pragian age.

Locality: (4) Koněprusy, E part of the "Na Voskopě" hill, a neptunian "Main Dyke" filled by rose and reddish biosparitic limestone in $\mathrm{E}$ wall of the quarry, the sites 25 and 26 described and illustrated by

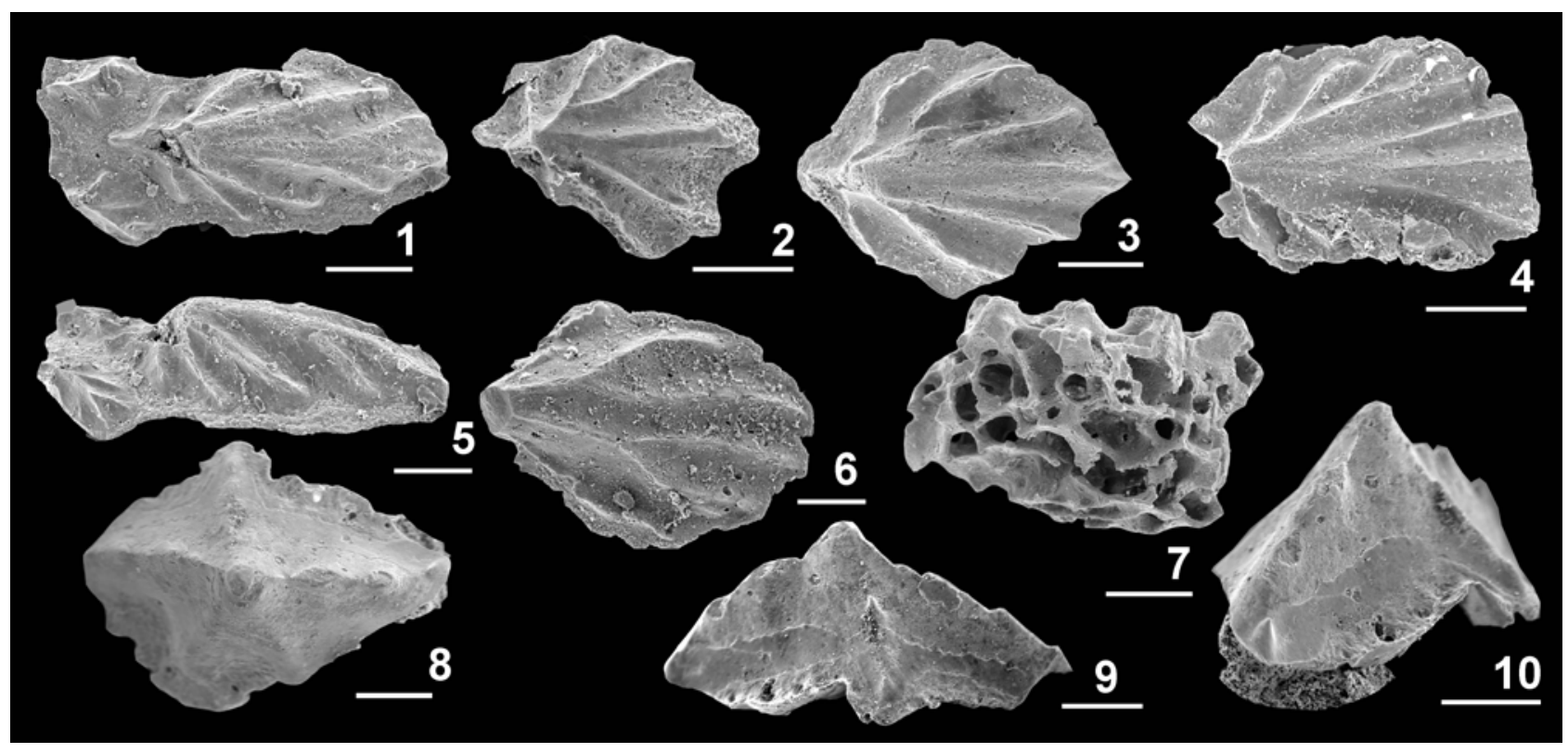

Plate III, 1-7 - Acanthothoraci gen. et sp. indet., Upper Emsian, Daleje-Třebotov Formation, Suchomasty Limestone; Koněprusy, Na Voskopě locality; Scale bars $100 \mu \mathrm{m} ; 1,5$ - dermal plate fragment with three tubercles in crown and latero-crown views, PCSCU 2116; 2 - dermal plate fragment in crown view, PCZCU 2117; 3 - dermal plate fragment in crown view, PCZCU 2118; 4 - dermal plate fragment in crown view, PCZCU 2119; 6 - dermal plate fragment in crown view, PCZCU 2120; 7 - dermal bone in lateral view, PCZCU 2121.

8-10 Chondrichthyes gen. et sp. indet., Upper Emsian, Daleje-Třebotov Formation, Suchomasty Limestone; Koněprusy, Na Voskopě locality; Scale bars $100 \mu \mathrm{m} ; 8-10$ - tooth-like plate in crown, lateral and oblique views, PCZCU 2122. 


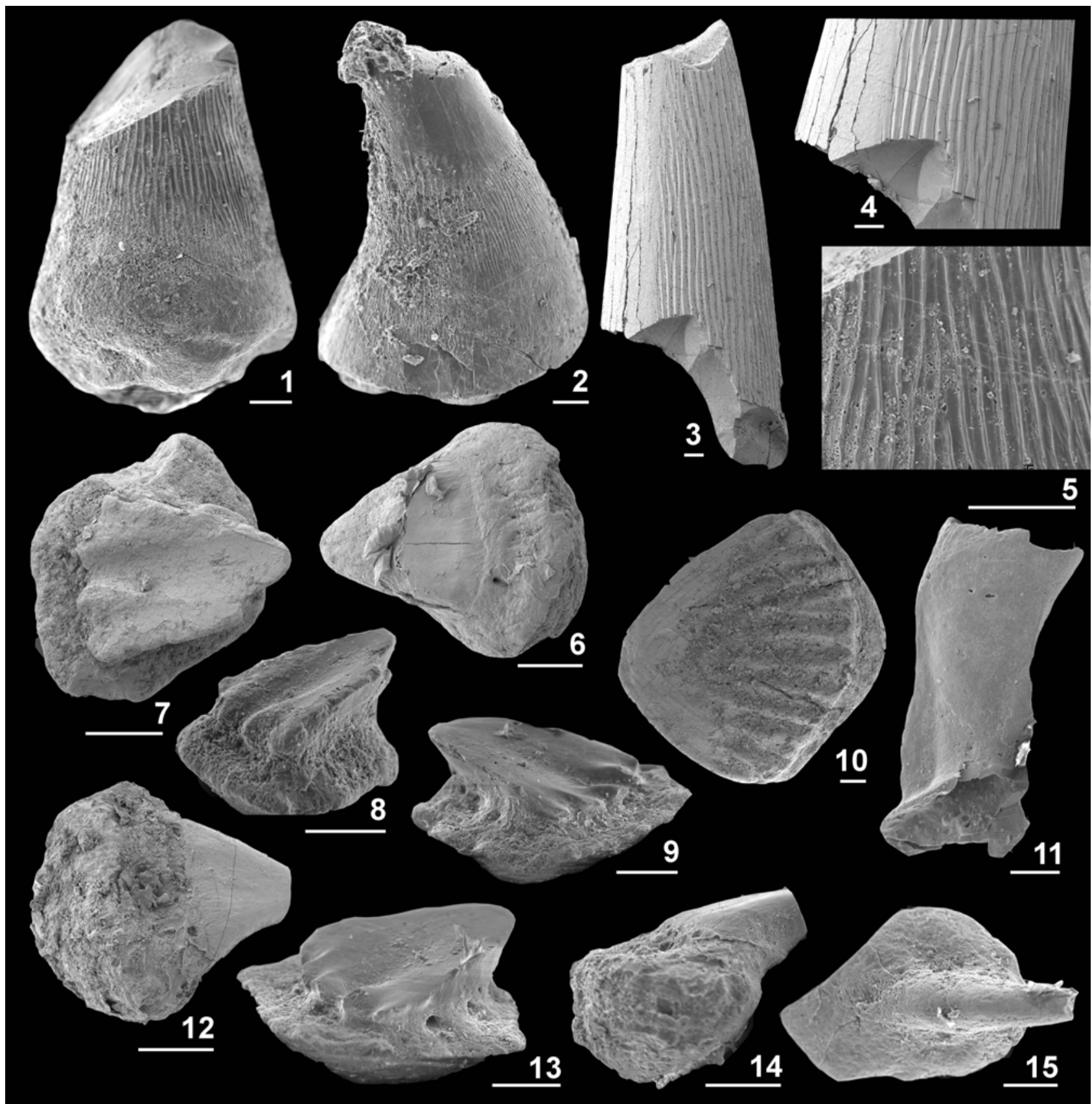

Plate IV, 1-5 - Sacropterigii gen. et sp. indet., Eifelian/Givetian transition, Srbsko Formation, Kačák Member, “dark interval” above the Acanthopyge Limestone, Koněprusy, Jirásek's Quarry locality; Scale bars $100 \mu \mathrm{m} ; 1,5$ - incomplete tooth in lateral view and detail of surface, PCZCU 2123; 2 - incomplete tooth in lateral view, PCZCU 2124; 3, 4 - incomplete tooth in lateral view, and detail of surface PCZCU 2100. 6, 12, 14 - Chondrichthyes gen. et sp. indet., tooth-like elements, Eifelian/Givetian transition, Srbsko Formation, Kačák Member, “dark interval” above the Acanthopyge Limestone, Koněprusy, Jirásek’s Quarry locality; Scale bars $100 \mu \mathrm{m} ; 6$ - tooth-like element in crown view, PCZCU 2129; 12, 14 - tooth-like elements in crown and side views, PCZCU 2128. 7-9, 13 - Nostolepis sp., Eifelian/Givetian transition, Srbsko Formation, Kačák Member, "dark interval" above the Acanthopyge Limestone, Koněprusy, Jirásek's Quarry locality; Scale bars $100 \mu \mathrm{m} ; 7,8$ - scale in crown and anterocrown views, PCZCU 2125; 9, 13 - scale in two latero-crown views, PCZCU 2126. 10 - Cheiracanthoides sp., Eifelian/Givetian transition, Srbsko Formation, Kačák Member, “dark interval” above the Acanthopyge Limestone, Koněprusy, Jirásek's Quarry locality; Scale bar $100 \mu \mathrm{m} ; 10$ - scale in crown view, PCZCU 2127. 11, 15 - Uncertain vertebrate remains, Eifelian/Givetian transition, Srbsko Formation, Kačák Member, “dark interval” above the Acanthopyge Limestone, Koněprusy, Jirásek's Quarry locality; Scale bar $100 \mu \mathrm{m} ; 11$ - onychodont (?) branchial, PCZCU 2130; 15 - palaeoniscoid (?) bone, PCZCU 2131. 
Chlupáč (1996), also reported as the locality 13 of Havlíček \& Kukal (1990). The vertebrate remains come from limestone with fossils of the Orbitoproetus-Scabriscutellum Community. Associated conodonts indicate the lower part of the $P$. serotinus Zone. Other phosphatic microfossils are represented by conodonts (for list see Mergl \& Jiménez, 2015), caudal spines of phyllocarid crustaceans, sclerites of Eurytholia, conulariids (Mergl et al., 2016) and diverse organophosphatic brachiopods (Mergl \& Jiménez, 2015). The non-phosphatic fauna is represented by highly diversified rhynchonelliform brachiopods, trilobites, cephalopods, and crinoids, with less abundant gastropods (Havlíček \& Kukal, 1990).

Class Placodermi M'Coy, 1848

Order ? Acanthothoraci Stensiö, 1944

Acanthothoraci gen. et sp. indet.

Plate III, figs 1-7

Description: The dermal bone plate fragments (Plate III, figs 1-6) bear a distinct ornament of several asymmetric elongated acute tubercles of uneven size. Some attain only one-third of the size of a large tubercle. The larger tubercles are $0.5 \mathrm{~mm}$ long, elongate, and with tips directed posterolaterally. The tubercle is covered by 7 to 10 radiating ridges. Irregular fragments of dermal bones associate the ornamented dermal plate fragments (Plate III, fig. 7).

Remarks: The plates with serrate ridges are similar to the ?palaeacanthaspid plates described by Burrow (2003; fig. 6G, H) from the Lochkovian of central New South Wales, Australia and to the plates of an unnamed placoderm by Burrow (1996; pl. 1, fig. D) from the same area. Similarly shaped plates were referred to Xiejiawanaspis pinus Burrow, Turner \& Wang, 2000 from the Emsian of Uzbekistan (Burrow et al., 2010a).

Occurrence: Locality 4.

\section{$4^{\mathrm{RD}}$ HORIZON: EIFELIAN-GIVETIAN TRANSITION, SRBSKO FORMATION, KAČÁK MEMBER, “DARK INTERVAL”}

Vertebrate micro-remains are fairly common and diverse in the upper half of the "dark interval" which has been correlated with the Kačák Member of the Srbsko Formation (Hladil et al., 1992; Hladil,
1993; Budil, 1995). Besides some irregular dermal bone fragments, some scales, fragments of bones with teeth cusps, and fragments of fin spines were identified. Isolated scales could be attributed to Nostolepis and Cheiracanthoides (Plate II, figs 1, 10; Plate IV, figs 7-9, 10, 13). Isolated (?) sarcopterygian teeth, bones and other scales of likely onychodont (Plate IV, fig. 11) and palaeoniscoid (Plate IV, fig. 15) affinity, and chondrichthyan teeth (Plate IV, figs 6, 12, 14) are present.

Locality (5). Eifelian-Givetian, Kačák Member, dark interval above the crinoidal Acanthopyge Limestone, Koněprusy, NE wall of the Jirásek Quarry. The gnathostome remains are associated with fragments of vascular plants (Rellimia), conodonts of the Polygnathus eiflius Zone, sclerites of Eurytholia and diverse organophosphatic brachiopods represented by obolids (Lingulipora, Paterula), acrotretids (Havlicekion, Opsiconidion), discinoids (Acrosaccus, Opatrilkiella, Orbiculoidea, Schizocrania), and siphonotretids (Orbaspina). Rhynchonelliform brachiopods are rare, with strophomenids, chonetids, productids, orthotetids, protorthids and atrypids determined. Proetid trilobites and ostracods are very rare. The abundant dacryoconarids include Nowakia otomari and styliolinids. The faunal association has a distinct deep water aspect in the Koněprusy area and is reflecting the Kačák Event (Hladil et al. 1992; Budil, 1995).

Class Acanthodii Owen, 1846

Family Climatiidae Berg, 1940

Genus Nostolepis Pander, 1856

Nostolepis sp.

Plate IV, figs 7-9, 13

Description: Small $(0.3-0.5 \mathrm{~mm})$ scale with a low and slightly convex rhombic base, which is larger than a low clearly anteriorly inclined triangular crown. The crown inclination is quite prominent, and it bears 4 to 5 ridges near the anterior margin. The posterior gently concave and rounded end of the crown is slightly extended over the base. The crown sides are smooth.

Remarks: The short crown of the scales resembles some species of Nostolepis described by Valiukevičius (1994) from the Lower Devonian of Taimyr. Among them N. curta Valiukevičius, 1994 
is the most similar. The crown of Nostovicina laticristata (Valiukevičius, 1994) figured in Valiukevičius (1994) on pl. 19, fig. 1 is also rather similar, but its base is more convex. Definite determination requires histological sectioning which is out of scope of this preliminary report.

Occurrence: Locality 5.

Genus Cheiracanthoides Wells, 1944

Cheiracanthoides sp.

Plate II, fig. 10; Plate IV, fig. 10

Description: The scale is rhombic in outline with a flat base and low neck. The crown is gently convex, with 12 or more low ridges, prominent in the anterior part of the crown. The posterior part is nearly smooth. The sides of the crown are smooth, the posterior end is rounded. Numerous pores are present along the anterior face of the neck.

Remarks: The scale is very similar to body scales of Cheiracanthoides comptus Wells, 1944. The scale also resembles an unnamed scale described by Burrow \& Murphy (2016) from Nevada and even more the scales referred to C. comptus from the Eifelian to Givetian of North Queensland (Pomeroy 1996) but the type species differs by a more elongate crown.

Occurrence: Locality 5.

Class Sarcopterygii Romer, 1955

Order incertae sedis

Sarcopterygii gen. et sp. indet.

Plate IV, figs 1-5

Description: The entire teeth-like remains are 2-3 $\mathrm{mm}$ long, narrowly conical, straight or gently curved, with a rounded and gently but irregularly convex base. Fine, gently wavy ridges fade towards the cusp creating a finely striated surface of the teeth. The ridges never merge but arise or fade in concave interspaces, which are about twice as wide as the ridges. A narrow pulp canal is present.

Remarks: The remains likely represent sarcopterygian teeth, because there is a narrow pulp cavity visible in cross section (Plate IV, fig. 1) and an excavate base. It is similar to teeth referred by Pomeroy (1996; fig. 5 B) as an Onychodontid indet.

Occurrence: Locality 5.

\section{CONCLUSIONS}

The rare vertebrate microremains from four stratigraphical horizons of the Prague Basin (Pragian, Lower Emsian, Upper Emsian, and Eifelian/ Givetian transition) indicate a moderate diversity and distinctive associations in particular horizons. There are scales, dermal bones and teeth of acanthodians, placoderms, chondrichthyans, and likely onychodontids. The highest diversity and abundance of microremains observed comes from the "dark interval" above the light coloured limestone sequence of the Acanthopyge Limestone in the Koněprusy area. This interval indicates a deepening related to the Kačák event (Hladil et al., 1992; Budil, 1995; Chlupáč, 1998a) and represents the Eifelian/Givetian boundary interval (dacryoconarid Nowakia otomari Zone; ? conodont Polygnathus eiflius Zone; Chlupáč, 1998a; Kalvoda, 1992).

\section{ACKNOWLEDGEMENT}

This study was supported by a grant of the Grant Agency of the Czech Republic GAČR No. P210-122018 (to MM). Authors are greatly indebted to Carole J. Burrow for a very helpful discussion.

\section{REFERENCES}

Barrande, J. 1872. Systême Silurien du Centre de la Boheme, $1^{\text {ère }}$ Partie: Recherches Paléntologiques, Supplement au Vol. I. Trilobites, Crustacés divers et Poissons. 617 pp. Prague, Paris.

Bayer, F. 1905. Katalog českých fossilních obratlovců (Fossilia vertebrata Bohemiae). 102 pp. Česká akademie císaře Františka Josefa pro vědy, slovesnost a umění, Praha.

Berg, L.S. 1940. Systema ryboobraznykh i ryb, nyne zhivushshikh i iskopaemykh [= System of fish-like and fishes, modern and extant forms]. Trudy zoologicheskogo instituta Akademiy Nauk SSSR 5(2), 87-517.

Budil, P. 1995. Demonstration of the Kačák event (Middle Devonian, uppermost Eifelian) at some Barrandian localities. Věstník Českého geologického ústavu 70(4), 1-24.

Burrow, C.J. 1996. Placoderm scales from the Lower Devonian of New South Wales, Australia. Modern geology 20, 351-369. 
Burrow, C.J. 2003. Earliest Devonian gnathostome microremains from central New South Wales (Australia). Geodiversitas 25(2), 273-288.

Burrow, C.J., Ivanov, A.O., Rodina, O. 2010a. Emsian vertebrate microremains from the Zinzilban section, Uzbekistan. Palaeoworld 19(1-2), 75-86.

Burrow, C.J., Lelièvre, H., Janjou, D. 2006. Gnathostome microremains from the Lower Devonian Jawf Formation, Saudi Arabia. Journal of Paleontology 80, 537-560.

Burrow, C.J., Murphy, M.A. 2016. Early Devonian (Pragian) vertebrates from the northern Roberts Mountains, Nevada. Journal of Paleontology 90(4), 734-740.

Burrow, C.J., Turner, S., Wang, S.T., 2000. Devonian microvertebrates from Longmenshan, Sichuan, China: Taxonomic assessment, 391452. In Blieck, A. \& Turner, S. (eds) Palaeozoic Vertebrate Biochronology and Global Marine/ Non Marine Correlation Final Report IGCP 328, 1991-1996. Courier Forschungsinstitut Senckenberg 223.

Burrow, C.J., Turner, S., Young, G. 2010b. Middle Palaeozoic microvertebrate assemblages and biogeography of East Gondwana (Australasia, Antarctica). Palaeoworld 19(1-2), 37-54.

Chlupáč, I. 1996. Neptunian dykes in the Koněprusy Devonian: Geological and palaeontological observations. Věstník Českého geologického ústavu 71(3), 103-208.

Chlupáč, I. 1998a. Devonian, 101-133. In Chlupáč, I. et al. Palaeozoic of the Barrandian (Cambrian to Devonian). Czech Geological Survey, Prague.

Chlupáč, I. 1998b. K faciím a stratigrafii spodnodevonského útesového komplexu u Koněprus. Věstník Českého geologického ústavu 73(1), 1-13.

Derycke, C., Goujet, D. 2011. Multicuspidate shark teeth associated with chondrichthyan and acanthodian scales from the Emsian (Devonian) of southern Algeria. Geodiversitas 33(2), 209226. DOI: $10.5252 / \mathrm{g} 2011 \mathrm{n} 2 \mathrm{a} 1$

Eastman, C.R. 1897. On the relations of certain plates in the Dinichthyds, with descriptions of new species. Bulletin of the Museum of Comparative Zoology 31(2), 19-44.

Ferrová, L., Frýda, J., Lukeš, P. 2012: High-resolution tentaculite biostratigraphy and facies developmnet the Early Devonian Daleje Event in the Barrandian (Bohemia): implication for global Emsian stratigraphy. Bulletin of Geosciences 87(3), 587-624.

Goujet, D. 1976. Les Poissons, 312-323. In Babin, C. et al. (eds) Les Schistes et Calcaires odévoniens de Saint-Céneré (Massif Armoricain, France): Sédimentologie, Paléontologie, Stratigraphie. Mémoires de la Societé Géologique et Minéralogique de Bretagne 19.

Gross, W. 1950. Die paläontologische und stratigraphische Bedeutung der Wirbertierenfaunen des Old Reds und der marinen altpaläozoischen Schichten. Abhanglungen der Deutschen Akademie der Wissenschaften zu Berlin. Mathematishnaturwissenschanftliche Klasse 1949(1), 1-130.

Gross, W. 1958. Über die älteste Arthrodiren-Gattung. Notizblatt des Hessischen Landesamtes für Bodenforschung zu Wiesbaden 86, 7-30.

Gross, W. 1959. Arthrodiren aus dem Obersilur der Prager Mulde. Palaeontographica A 113, 1-3, 1-35.

Gross, W. 1973. Kleinschuppen, Flossenstacheln und Zähne von Fische aus Europäischen und Nordamerikanischen Bonebeds des Devons. Palaeontographica, Abt. A 142, 4-6, 51-155.

Hanke, G.F., Wilson, M.V.H., Saurette, F.J. 2013. Partial articulated specimen of the Early Devonian putative chondrichthyan Polymerolepis whitei Karatajūtè-Talimaa, 1968, with an anal fin spine. Geodiversitas 35(3), 529-543.

Havlíček, V. 1998. Review of brachiopods in the Chapel Coral Horizon (Zlichov Formation, lower Emsian, Lower Devonian, Prague Basin). Věstník Českého geologického ústavu 73(2), 113-132.

Havlíček, V., Kukal, Z. 1990. Sedimentology, benthic communities, and brachiopods in the Suchomasty (Dalejan) and Acanthopyge (Eifelian) Limestones of the Koněprusy area (Czechoslovakia). Sborník geologických věd, Paleontologie 31, 105-205.

Havlíček, V., Racheboeuf, P.R. 1979. Chonetacea (Brachiopodes) du Silurien et du Dévonien de Bohême (Tchécoslovaquie). Annales de Paléontologie (Invertébrés), 65(2), 69-138.

Hladil, J. 1993. Tabulatomorphs and stromatoporoids below and above the upper boundary of the Acanthopyge Limestone (Eifelian/Givetian transition interval, Central Bohemia). Věstník Českého geologického ústavu 68(2), 27-42. 
Hladil, J., Beroušek, P., Lukeš, P. 1992. Temné vápencové vrstvy při stropu akantopygových vápenců u Koněprus - otomari-Kačák event. Zprávy o geologických výzkumech v roce 1991, 53-55.

Huxley, T.H. 1880. On the application of the laws of evolution to the arrangement of the Vertebrata and more particularly the Mammalia. Proceedings of the Zoological Society of London 1880, 649-662.

Kalvoda, J. 1992. The youngest conodont fauna of the Barrandian. Scripta 22, 61-63.

Karatajūtè-Talimaa, V.N. 1968. Noviye telodonti, heterostraki i artrodiri iz Chortkovskogo Horizonta Podolii [New thelodonts, heterostracans and arthrodires from the Chortkov Stage of Podolia], 33-42. In Obruchev D.V. (ed.) Ocherki po Foligenii $i$ Sistematike iskopae- mikh Rib $i$ Bescheliustnikh [Sketches in phylogenesis and taxonomy of fossil fishes and agnatha]. Nauka, Moscow [in Russian].

Koenen, A. von 1895. Ueber einige Fischreste des norddeutschen und Böhmischen Devons. Abhandlungen der Gesellschaft der Wissenschaften in Göttingen, Mathematisch-Physikalische Klasse 40(2), 1-37.

Märss, T. 1997. Vertebrates of the Pridoli and Silurian-Devonian boundary beds in Europe. Modern Geology 21, 17-41.

M'Coy, F. 1848. On some new fossil fish of the Carboniferous period. Annals and Magazine of Natural History 2, 1-10.

Mergl, M. 2001. Lingulate brachiopods of the Silurian and Devonian of the Barrandian (Bohemia, Czech Republic). Acta Musei Nationalis Pragae, series B - Historia Naturalis 57(1-2), 1-49.

Mergl, M. 2008. Lingulate brachiopods from the Acanthopyge Limestone (Eifelian) of the Barrandian, Czech, Republic. Bulletin of Geosciences 83(3), 281-298.

Mergl, M., Ferrová, L. 2009. Lingulate brachiopods from the Chýnice Limestone (upper Emsian, Barrandian; Czech Republic). Bulletin of Geosciences 84(3), 525-546.

Mergl, M., Frýda, J., Ferrová, L 2016. Armoured test of Early Devonian Mesoconularia (Conulariida) from the Prague Basin (Czech Republic): probable adaptation to increased predation pressure. Bulletin of Geosciences 91(3), 561-581.
Mergl, M., Jiménez, A. 2015. Lingulate brachiopods from the Suchomasty Limestone (upper Emsian) of the Barrandian, Czech Republic. Bulletin of Geosciences 90(1), 173-193.

Otto, M. 1999. New finds of vertebrates in the Middle Devonian Brandenberg Group (Sauerland, Northwest Germany). Paläontologiche Zeitschrift 73(1/2), 113-131.

Owen, F.R.S. 1846. Lectures on the comparative anatomy and physiology of the vertebrate animals. Part I. Fishes. 304 pp. Longman, Brown, Green, and Longmans.

Pander, C.H. 1856. Monographie der fossilen Fische des silurischen Systems der RussischBaltischen Gouvernements. 91 pp. St. Petersburg: Akademie der Wissenschaften.

Pomeroy, A.M. De 1994. Mid-Devonian chondrichthyan scales from the Broken River, north Queensland, Australia. Memoirs of the Queensland Museum 37(1), 87-114.

Pomeroy, A.M. De 1996. Biostratigraphy of Devonian microvertebrates from Broken River, North Queensland. Records of the Western Australian Museum 17, 417-437.

Romer, A.S. 1955. Herpetichthyes, Amphibioidei, Choanichthyes or Sarcopterigii? Nature 176, 126.

Růžička, R. 1929. Psammosteus (Ganosteus) Perneri n. sp. Contribution a la connaissance des poissons du Paléozoique de la Bohême. Věstník Státního geologického ústavu Československé republiky 5, 166-172.

Stensiö, E. 1944. Contributions to the knowledge of the vertebrate fauna of the Silurian and Devonian of western Podolia. II. Notes on two arthrodires from the Downtonian of Podolia. Arkiv für Zoologi 35(9), 1-83.

Valiukevičius, J.J. 1994. Akantodi i ikh stratigrafitcheskoye znatcheniye, 131-197, 236-243. In Tcherkesova, S.V., Karatajute-Talimaa, V.N. \& Matukhion, R.G. (eds) Stratigrafiya i Fauna nizhnedevonskikh otlozheniy Taryeiskogo opornogo razreza (Taimyr). Izdatelstvo Nedra. St. Petersburg [in Russian].

Vaškaninová, V., Kraft, P. 2014a. The largest Lower Devonian placoderm - Antineosteus rufus sp. nov. from the Barrandian area (Czech Republic). Bulletin of Geosciences 89(3), 635-644.

Vaškaninová, V., Kraft, 2014b. Dynamics of placoderm distribution in the Prague Basin (Czech 
Republic). Geologiska Föreningens i Forhanglingar 136(1), 281-285.

Vaškaninová, V., Kraft, P. 2016. A unique occurrence of a psammosteid heterostracan on the peri-Gondwanan shelf in the Lower/Middle Devonian boundary marine deposits. - Fossil Imprint 72(3-4), 155-160.

Vaškaninová, V., Ahlberg, P.E. 2017. Unique diversity of acanthothoracid placoderms (basal jawed vertebrates) in the Early Devonian of the Prague Basin, Czech Republic: A new look at $R a$ dotina and Holopetalichthys. PLoS ONE 12(4), e0174794. https://doi.org/10.1371/journal.pone.0174794

Vodrážková, S., Frýda, J., Suttner, T., Koptíková, L., Tonarová, P. 2013. Environmental changes close to the Lower-Middle Devonian boundary, the Basal Choteč event in the Prague Basin (Czech Republic). Facies 59(2), 425-449.

Wang, R. 1993. Taxonomie, Paleoökologie und Biostratigraphie der Mikroichthyolithen aus dem Unterdevon Keltiberiens, Spanien. Courier Forschungsinstitut Senckenberg 161, 1-205.

Wells, J. W. 1944. Fish remains from the Middle Devonian Bone Beds of the Cincinnati Arch region. Palaeontographica Americana 3, 99-160.

Young, G. C., Burrow, C. J. 2004. Diplacanthid acanthodians from the Aztec Siltstone (late Middle Devonian) of southern Victoria Land, Antarctica. Fossils and Strata 50, 23-43. 